\title{
In Vivo Generation of Organs by Blastocyst Complementation: Advances and Challenges
}

\author{
Konstantina-Maria Founta, Costis Papanayotou \\ Department of Basic Science, Biomedical Research Foundation of the Academy of Athens, Athens, Greece
}

The ultimate goal of regenerative medicine is to replace damaged cells, tissues or whole organs, in order to restore their proper function. Stem cell related technologies promise to generate transplants from the patients' own cells. Novel approaches such as blastocyst complementation combined with genome editing techniques open up new perspectives for organ replacement therapies. This review summarizes recent advances in the field and highlights the challenges that still remain to be addressed.

Keywords: Blastocyst complementation, Chimeras, Organ generation, Transplantation

\section{Introduction}

Thousands of people worldwide suffer from end-stage diseases, for which the last resort for survival is organ transplantation. As available transplants are limited, many patients are obliged to wait on long lists, surviving on medical procedures that undermine their quality of life and often dying of organ failure (1). Even patients who have undergone transplantation surgery risk severe complications. Since the transplants originate from different donors, the recipients' immune system attempts to reject them. The patients are typically put for the rest of their life on immunosuppressive drugs, which cause unwanted side effects such as increased likelihood of infections and

Received: July 1, 2021, Revised: August 5, 2021,

Accepted: August 8, 2021, Published online: October 31, 2021 Correspondence to Costis Papanayotou

Department of Basic Science, Biomedical Research Foundation of the Academy of Athens, Athens 11527, Greece

Tel: +30-210-6597199, Fax: +30-210-6597545

E-mail: cpapana@bioacademy.gr

(c) This is an open-access article distributed under the terms of the Creative Commons Attribution Non-Commercial License (http://creativecommons.org/ licenses/by-nc/4.0/), which permits unrestricted non-commercial use, distribution, and reproduction in any medium, provided the original work is properly cited.

Copyright (c) 2022 by the Korean Society for Stem Cell Research
Post-Transplantation Lymphoproliferative Disorders (2).

\section{Stem cells and regenerative medicine}

Transplants generated from the patient's own cells would not only solve the problem of organ shortage, but also bypass the complication of incompatibility and tissue rejection by the host immune system. Induced Pluripotent Stem Cells (iPSCs) hold great promise for regenerative medicine, including organ replacement therapies $(3,4)$. iPSCs were discovered only 15 years ago $(5,6)$ and they are now routinely produced from adult somatic cells by the forced transient expression of four transcription factors (OCT4, SOX2, KLF4 and cMYC). They constitute an unlimited source of autologous cells that can be differentiated into virtually any cell type and provide immunocompatible tissues for transplantation. To this end, iPSCs have already been successfully used in animal models of diabetes, liver injury, myocardial infarction and Parkinson's disease (7-10).

However, despite the progress that has been made in use of iPSCs for cell therapies, generation of transplantable organs has so far met with little success. Organs are complex three-dimensional structures, built during embryonic development thanks to a series of inductive interactions between different tissues, followed by precisely regulated cell division, differentiation and migration. 
These events cannot be easily recapitulated in vitro. Therefore, it is not surprising that efforts to populate synthetic or decellularized organ scaffolds with differentiated stem cells have not so far succeeded in producing fully grown, fully functional organs, fit to be transplanted into host organisms (11). There is instead a growing belief that the best, if not the only, system that can recapitulate the sequence of events leading to their formation is the embryo itself. Based on this idea over the last decade an increasing number of investigators is trying to produce allogeneic (belonging to the same species) and ultimately xenogeneic (belonging to different species) organs in the context of developing intraspecies or interspecies chimeric embryos (embryos composed of a mixture of cells that derive from at least two organisms belonging to the same or different species). The end goal is to generate personalized human organs for transplantations, using as starting material the patient's iPSCs, in large livestock animals.

To this end, efforts are being made to use animals as hosts for the production of human transplants, by instructing their embryos to form the organ in question from human cells. Pigs are currently the favorite host due to similarities in organ size, anatomy and physiology to humans but also because of their easy breeding and relatively large litter. To achieve this objective the method of choice is blastocyst complementation.

\section{Blastocyst Complementation: Advances}

\section{The first groundbreaking studies}

In blastocyst complementation a host blastocyst is genetically engineered and lacks a gene that is indispensable for the development of the organ of interest. In the host embryo this "agenesis" phenotype creates an empty "developmental niche". The mutant blastocysts are injected with wild type pluripotent stem cells belonging to a donor from the same or different species. Donor cells complement the host embryo, occupy the empty niche and form the missing organ. The embryo develops into a chimera composed of a mixture of mutant host and wild type donor cells, the organ in question however is formed exclusively by donor cells (12).

Blastocyst complementation was first demonstrated when wild type mouse embryonic stem cells (mESCs) were injected into Rag2 mutant blastocysts that grew into mice unable to produce $\mathrm{T}$ and B lymphocytes. Donor ESCs developed successfully into lymphocytes - in fact all B and $\mathrm{T}$ lymphocytes of the chimeric mice were exclusively derived from these cells (13). It was later shown that wild type ESCs injected into Idl/3- blastocysts rescue the car- diac defect of the mutations by a cell non-autonomous mechanism. Indeed a small number of donor cells is sufficient to revert the embryonic lethal phenotype. In this case however, since the idl/3 mutations did not produce an agenesis phenotype, the heart was chimeric, consisting of both host and donor cells (14).

In a groundbreaking study, Nakauchi and colleagues showed that blastocyst complementation could be applied to generate complex three-dimensional organs derived exclusively from donor cells: wild type mouse ESCs or iPSCs were injected into Pdx1 mutant blastocysts that develop into pancreas-deficient mice. Both ESCs and iPSCs were able to colonize the empty developmental niche and produce a functional pancreas rescuing the lethal phenotype of the host mutants. The developed pancreas derived almost exclusively from the wild type donor cells. It was also shown that mouse Pdxl mutant blastocysts could be complemented by rat ESCs or iPSCs. The resulting chimeras had a functional pancreas consisting almost exclusively of rat cells. This confirmed that organs derived from donor iPSCs can be generated into a xenogeneic environment and paved the way for the production of human transplants by a patient's iPSCs in large animal embryos (15). Subsequently blastocyst complementation successfully produced allogeneic pancreases in apancreatic pigs, demonstrating that this principle can also be applied to large animals (16). However nerves and vasculature in the allogeneic/xenogeneic pancreatic tissue were still composed largely of host cells, making these organs unfit for transplantation. Nevertheless, mouse pancreas islets grown into a rat host and grafted under the renal capsule of diabetic mice, achieved long-term glycaemic control, demonstrating their suitability for transplantation (17).

\section{Generation of various tissues and organs via blastocyst complementation}

Since then, numerous studies have been performed using blastocyst complementation to produce various organs with mixed results. Wild type rat ESCs colonize numouse blastocysts that lack thymus and form the missing organ. The generated thymus is functional and consists entirely of rat cells (18).

Sall1- mouse blastocysts showing a kidney agenesis phenotype can be complemented by mouse ESCs or iPSCs and produce the absent organ in an intraspecies chimera. Rat stem cells are unable to do the same in an interspecies context, however, in the reverse experiment, mouse stem cells rescued the anephrogenesis phenotype of Sall1- rat embryos generating xenogeneic kidneys. Success was limited though, as chimeric embryos died upon birth. In a 
separate study mouse or rat nephron progenitor cells were transplanted under the renal capsule of E13.5 mouse embryos and formed kidneys both ex vivo and in vivo. However this approach is technically very demanding and has not been widely used. Moreover formation of the allogeneic/xenogeneic organ takes place ex situ raising questions about its transplantability. At all events, although the generated kidneys were almost exclusively composed of donor cells, the collecting tubes, ureter, bladder, blood vessels and nerves consisted largely of host cells (19-23).

Attempts have also been made to make hearts by blastocyst complementation, however this organ proved even more averse to such manipulations. The process of cardiogenesis is complex, involving several key genes such as Mesp1, Tbx5, Nkx2.5 and Gata4, none of which has an agenesis phenotype. As a result, efforts to produce a heart by complementing blastocysts mutant for the early cardiac marker Nkx2.5 led to chimeric organs consisting of both host and donor cells (24).

Eyes formed by complementing Pax6 mutant blastocysts were also chimeric (24). More recently Bama miniature pig embryos mutant for MITF and complemented with wild type blastomeres developed intact eyes enriched in donor cells. In fact almost all the retinal pigmented epithelium cells and corneal epithelial cells of the chimeric piglets derived from wild type donor cells (25).

Wild type mouse ESCs can also complement Neurog1 heterozygous mutant blastocysts that develop into mice with severe inner ear malformations. In the resulting chimeras spiral ganglion neurons of the inner ear consist mostly of donor cells. The few complemented Neurogl homozygous mutant blastocysts obtained in this study showed very low chimerism and thus were not suitable for analysis of blastocyst complementation in a homozygous mutant context (26).

More recently attempts were made to produce allogeneic mouse lungs by blastocyst complementation. Fgf receptor 2 was the mutation of choice, however, as the gene is expressed in various tissues, a conditional knock-out approach was used in order to restrict deletion of the gene in the developing foregut. This approach resulted in the generation of allogeneic lung epithelium but not of other lung cell types. Conditional Ctnnbl- blastocysts were also complemented and formed both lung and trachea epithelium but again no other lung cell types were produced (27). Subsequently Fgf10 mutant blastocysts were used and these produced allogeneic lungs, with all cell types except for nerve cells being derived from donor cells. However few chimeras survived and lungs contained also host cells, presumably because Fgfl0 is a signaling mole- cule and consequently donor cells non-autonomously rescued host cells from the deleterious effect of the mutation. This study demonstrated the limitations in using mutated genes expressing secreted factors in blastocyst complementation studies (28). Fgf10 mutant blastocysts were also used in another study to generate allogeneic thyroids that were largely, but not exclusively, derived from donor cells (29). An even more recent study used Nkx2-1 mutant embryos, which lack pulmonary and thyroid tissues. After ESC complementation pulmonary and thyroid structures were restored. Respiratory epithelial cell lineages in these chimeras were derived almost entirely from wild type donor cells, whereas endothelial, immune, and stromal cells were mosaic (30).

Wild type mouse and pig pluripotent stem cells successfully complemented HHEX- mouse and pig embryos respectively to restore normal liver development, although it is not clear whether the generated allogeneic organs are exclusively derived from donor cells or from a mixture of host and donor cells $(23,31)$.

Mice mutant for Runx2, a master transcription factor for osteoblastogenesis, fail to form mineralized skeleton and bone marrow. Injection of wild type mouse ESCs and iPSCs rescues the mutant phenotype. In particular, donor cell derived osteoblasts can reconstitute the hematopoietic niche in vivo, and above a contribution threshold of $\sim 40 \%$ can restore near normal gross skeletal morphology. Similar results were obtained when blastocysts, genetically engineered to ablate the osteoblast compartment, were injected with wild type mouse ESCs and iPSCs (32).

Pig embryos mutant for MYF5, MYOD and MYF6 lack native skeletal muscle. When such mutant blastocysts were injected with wild type porcine blastomeres, the generated intraspecies chimeras were viable and displayed normal histology, morphology and function. Human iPSCs also complemented the mutant blastocysts with considerable efficiency and the chimeric embryos contained humanized muscle (33).

Wild type rat or mouse ESCs can complement rat Prdm14 mutant blastocysts (that grow into animals lacking the germline) and generate chimeras producing allogeneic or xenogeneic gametes. Germ cells in these chimeric animals consist exclusively of donor cells. Interestingly these chimeras can be used to generate mutant offspring with high efficiency as exemplified in the case of Pax2/ Pax8 double mutants that lack both kidneys and ureters (as opposed to the Sall1 mutant animals described above, lacking only the kidneys). Production of such double knock-out animals with traditional Mendelian crosses is highly inefficient with only $1 / 16$ of the progeny of double 
heterozygous mutants being double homozygotes. Instead, chimeras produced by complementing Prdm14- blastocysts with Pax2/Pax8 double mutant ESCs, do have kidneys but all their gametes are Pax2/Pax8 -/-. When two such chimeric animals are crossed all their progeny are Pax $2 / \operatorname{Pax} 8$ double mutant and show the anephrogenic phenotype (34).

\section{Vascularization of generated organs by blastocyst complementation}

As mentioned above, most organs produced by blastocyst complementation are vascularized and innervated by host tissues, making them unfit for transplantation, since the blood vessels and nerves of the transplant will trigger an immune response in the recipient, resulting in its rejection. To address this issue, attempts have been made to generate vasculature in mutant embryos: wild type mouse or rat ESCs complemented Flk1- mouse blastocysts lacking hematoendothelial lineages and produced allogeneic endothelium and blood (but not blood vessel walls) $(35,36)$. Another study used Etv2 mutant mouse blastocysts and generated allogeneic endothelium and blood (37). Remarkably Etv2- pig blastocysts were also successfully complemented by human iPSCs giving rise to endothelium exclusively derived from donor human cells (23). There is now hope that the Etv2 mutation could be combined with mutations in other genes to generate organs with reduced immunogenicity. In fact $\mathrm{Pdx} 1 / \mathrm{Kdr}$ (Flk1) double mutant pig morulae have already been complemented by wild type pig blastomeres to form an allogeneic vascularized pancreas (23).

\section{Generation of mutant hosts by gene editing}

Blastocyst complementation in animals other than mice depends on fast, easy and reliable methods to knock out specific genes in their embryos. Recent advances in gene editing techniques have already made this possible. TALENs and CRISPR/Cas9 in conjunction with somatic cell nuclear transfer or directly in zygotes of rats, pigs and sheep are being used to knock out specific genes and generate the respective organ agenesis phenotypes, allowing complementation of the mutant embryos by wild type allogeneic or xenogeneic pluripotent stem cells (16, 17, 21-24, 28, 38, 39).

\section{Blastocyst Complementation: Challenges}

\section{Ethical issues posed by interspecies chimeras}

Blastocyst complementation studies have raised hopes for the generation of personalized human organs in live- stock animals. Nevertheless, they have also revealed various challenges that need to be addressed. One major problem with considerable ethical ramifications is that wild type cells colonize not only the empty developmental niche but also all other body parts including the brain and the gonads. This suggested that interspecific chimeras created using human PSCs, may exhibit human-like consciousness if a significant number of donor cells end up in the host brain, posing serious ethical issues. Moreover, there is also the risk of the host animal producing human germ cells. In fact donor derived germ cells have been reported in xenogeneic hosts (18). A third issue is the possibility that interspecies chimeras may exhibit human-like appearance. Efforts have to be made, therefore, to restrict donor cells in tissues that will generate only the missing organs. It has been proposed to manipulate injected ESCs so as to harbor suicide genes that would kill them as soon as they differentiate into an undesired phenotype, however this idea has not been further investigated. Instead it has been shown that Mixll-expressing mESCs, complementing apancreatic mouse blastocysts are specifically guided to endodermal tissues circumventing the problem of embryo-wide colonization of the host embryo (40). Alternatively while Prdm14-/Otx2- mESCs complement mouse Pdx1blastocysts and form functional pancreases they do not contribute to either gametes or the brain of the chimeras (41). Furthermore mouse endoderm progenitors injected into blastocysts engraft preferably into the developing endoderm (42).

\section{Organs refractory to blastocyst complementation}

Another technical barrier is that mutations that interfere with the development of specific organs could also affect other aspects of the host physiology and even have deleterious effects, which make their use in blastocyst complementation assays impractical. This has been exemplified by the attempts to make allogeneic and xenogeneic kidneys by complementation of Sall1 mutant blastocysts. Newborn chimeric mice have normal-looking kidneys, almost exclusively derived from mouse ESCs or iPSCs but they die soon after birth. Although the reason is not clear, the absence of intragastric milk and the fact that Sall1 is expressed not only in nephrogenic tissues but also in the brain, suggests that the chimeric pups may not have developed properly the nerve pathways required for suckling function and hence are unable to nurse (19). Recent studies have used a conditional blastocyst complementation approach, which address such complications (20, 27).

Furthermore, organs such as the heart are not amenable to blastocyst complementation. As there is no single muta- 
tion resulting in an empty cardiac developmental niche, the chimera's heart is a mixture of host and donor cells. When blastocysts mutant for the early cardiac marker Nkx2.5 were used as hosts, the generated hearts were not exclusively formed by, but rather enriched in rat cells (24). This happened because Nkx2.5 mutants do form a heart, albeit malformed and dysfunctional (43) and as a result complementation host cells were not excluded from the developing organ. Moreover, the chimeric embryos did not survive to term and this may be due to the expression of the gene in other tissues as well and therefore its probable involvement in other developmental and/or physiological processes indispensable for survival.

\section{Inability of human stem cells to colonize blastocysts}

When interspecies chimeras are considered, additional challenges arise. In general, chimerism is lower in the interspecies than in the intraspecies context. Its efficiency is tissue dependent, as it is different for different organs. Moreover, high interspecies chimerism causes abnormalities or even death (44). Human PSCs injected into mouse blastocysts, initially localize in the ICM but in subsequent stages of the in vitro embryo development they are excluded from host tissues (45). It has been realized for quite some time that mouse and human ESCs derived from the Inner Cell Mass of embryos are different and correspond to distinct phases of pluripotency (naive and primed respectively) (46-48). Human ESCs are similar both morphologically and physiologically to mouse Epiblast Stem Cells that are isolated from the post-implantation epiblast (49). Successful chimerism requires host and donor cells to be synchronized. For this reason hESCs grafted into the post-implantation mouse epiblast can integrate, proliferate, migrate and differentiate according to their transplantation position (50). Over the last few years, different culture conditions have been assessed and different pluripotent states (naive, primed and intermediate) have been achieved for hESCs in order to maximize interspecies chimera formation efficiency (51-59). However a recent report suggests that even naive human PSCs are inherently unfit for chimera formation as, upon dissociation and injection into host embryos, they stop dividing and undergo premature differentiation (60). On the other hand, it has been observed that pluripotent stem cells grafted heterochronically in embryos undergo apoptosis (61-63). Inhibiting apoptosis increases the efficiency of chimera formation in such cases. Indeed, both naive and primed hPSCs overexpressing antiapoptotic genes, contribute to all three germ lines and extraembryonic tissues of mouse, rabbit and pig embryos $(42,64,65)$. Finally, a recent study showed that hESCs in culture are outcompeted by mESCs due to a mechanism involving genes related to the NF- $\kappa \mathrm{B}$ signaling pathway, suggesting that targeting this pathway in human donor cells could overcome this competition, thereby improving their survival and chimerism in xenogeneic embryos (66).

\section{Xenobarrier to interspecies chimera formation}

Notwithstanding the inherent capability of human stem cells to form chimeras, interspecies compared to intraspecies chimerism is much lower. As chimera formation between rats and mice is more efficient than between less related species but less efficient than intraspecies chimera formation, there seems to be an evolutionary aspect to the limitations observed in interspecies chimerism: the more distant phylogenetically the two species are, the more difficult it is to participate in chimera formation. Possible causes for this "xenobarrier" are different rates of cell proliferation and differentiation, divergent developmental programs, varying signaling pathways, incompatibility between ligands and receptors, and differences in the affinity of adhering molecules (67). The fact that humans and pigs are in many respects more similar than humans and mice, suggests that the xenobarrier between the two former species may prove easier to cross. Nevertheless, such an interspecies barrier does exist and this is why active research is currently being conducted between different species in order to elucidate its mechanisms and propose possible strategies to overcome it (68-71). Interestingly, it was recently reported that deletion of insulin-like growth factor 1 receptor (Igflr) in mouse blastocysts significantly facilitates their colonization by both mouse and rat donor cells resulting in highly chimeric animals (72). This manipulation may also facilitate interspecies chimera formation between species evolutionary more divergent such as humans and pigs. At all events, in order to achieve high degrees of interspecies chimerism and adequate generation of xenogeneic organs, both optimization of donor pluripotent cells has to be accomplished and the interspecies barrier has to be overcome.

\section{Conclusions}

Over the last decade, significant progress has been made in the effort to generate xenogeneic organs for transplantation by blastocyst complementation. Recent advances in genome editing techniques greatly facilitate this effort. Nevertheless, considerable challenges still remain and need to be addressed before such transplants can be routinely produced. Success in this endeavor would solve 
the problem of transplant shortage and help thousands of patients worldwide in need of organ replacement therapies to receive the life-saving treatment. It would also provide them with autologous grafts resolving the complications of tissue incompatibility and rejection. Finally, it would address serious social issues, such as organ trafficking, transplant tourism, and transplant commercialism (73). Research with interspecies chimeras raises various ethical questions, however the benefits to public health are of such importance, that the scientific community has to proceed in this new exciting field with transparency and within the limits set by reasonable ethical concerns.

\section{Potential Conflict of Interest}

The authors have no conflicting financial interest.

\section{References}

1. Girlanda R. Deceased organ donation for transplantation: challenges and opportunities. World J Transplant 2016;6: 451-459

2. Dierickx D, Habermann TM. Post-transplantation lymphoproliferative disorders in adults. N Engl J Med 2018;378: 549-562

3. De Vos J, Bouckenheimer J, Sansac C, Lemaître JM, Assou S. Human induced pluripotent stem cells: a disruptive innovation. Curr Res Transl Med 2016;64:91-96

4. Karagiannis P, Eto K. Ten years of induced pluripotency: from basic mechanisms to therapeutic applications. Development 2016;143:2039-2043

5. Takahashi K, Yamanaka S. Induction of pluripotent stem cells from mouse embryonic and adult fibroblast cultures by defined factors. Cell 2006;126:663-676

6. Takahashi K, Tanabe K, Ohnuki M, Narita M, Ichisaka T, Tomoda K, Yamanaka S. Induction of pluripotent stem cells from adult human fibroblasts by defined factors. Cell 2007;131:861-872

7. Vegas AJ, Veiseh O, Gürtler M, Millman JR, Pagliuca FW, Bader AR, Doloff JC, Li J, Chen M, Olejnik K, Tam HH, Jhunjhunwala S, Langan E, Aresta-Dasilva S, Gandham S, McGarrigle JJ, Bochenek MA, Hollister-Lock J, Oberholzer J, Greiner DL, Weir GC, Melton DA, Langer R, Anderson DG. Long-term glycemic control using polymer-encapsulated human stem cell-derived beta cells in immune-competent mice. Nat Med 2016;22:306-311

8. Tolosa L, Caron J, Hannoun Z, Antoni M, López S, Burks D, Castell JV, Weber A, Gomez-Lechon MJ, DubartKupperschmitt A. Transplantation of hESC-derived hepatocytes protects mice from liver injury. Stem Cell Res Ther 2015;6:246

9. Bellamy V, Vanneaux V, Bel A, Nemetalla H, Emmanuelle Boitard S, Farouz Y, Joanne P, Perier MC, Robidel E, Mandet C, Hagège A, Bruneval P, Larghero J, Agbulut O, Menasché P. Long-term functional benefits of human em- bryonic stem cell-derived cardiac progenitors embedded into a fibrin scaffold. J Heart Lung Transplant 2015;34:11981207

10. Kriks S, Shim JW, Piao J, Ganat YM, Wakeman DR, Xie Z, Carrillo-Reid L, Auyeung G, Antonacci C, Buch A, Yang L, Beal MF, Surmeier DJ, Kordower JH, Tabar V, Studer L. Dopamine neurons derived from human ES cells efficiently engraft in animal models of Parkinson's disease. Nature 2011;480:547-551

11. Dey M, Ozbolat IT. 3D bioprinting of cells, tissues and organs. Sci Rep 2020;10:14023

12. Crane AT, Aravalli RN, Asakura A, Grande AW, Krishna VD, Carlson DF, Cheeran MC, Danczyk G, Dutton JR, Hackett PB, Hu WS, Li L, Lu WC, Miller ZD, O'Brien TD, Panoskaltsis-Mortari A, Parr AM, Pearce C, RuizEstevez M, Shiao M, Sipe CJ, Toman NG, Voth J, Xie H, Steer CJ, Low WC. Interspecies organogenesis for human transplantation. Cell Transplant 2019;28:1091-1105

13. Chen J, Lansford R, Stewart V, Young F, Alt FW. RAG-2deficient blastocyst complementation: an assay of gene function in lymphocyte development. Proc Natl Acad Sci U S A 1993;90:4528-4532

14. Fraidenraich D, Stillwell E, Romero E, Wilkes D, Manova K, Basson CT, Benezra R. Rescue of cardiac defects in id knockout embryos by injection of embryonic stem cells. Science 2004;306:247-252

15. Kobayashi T, Yamaguchi T, Hamanaka S, Kato-Itoh M, Yamazaki Y, Ibata M, Sato H, Lee YS, Usui J, Knisely AS, Hirabayashi M, Nakauchi H. Generation of rat pancreas in mouse by interspecific blastocyst injection of pluripotent stem cells. Cell 2010;142:787-799

16. Matsunari H, Nagashima H, Watanabe M, Umeyama K, Nakano K, Nagaya $M$, Kobayashi T, Yamaguchi T, Sumazaki R, Herzenberg LA, Nakauchi H. Blastocyst complementation generates exogenic pancreas in vivo in apancreatic cloned pigs. Proc Natl Acad Sci U S A 2013;110: 4557-4562

17. Yamaguchi T, Sato H, Kato-Itoh M, Goto T, Hara H, Sanbo M, Mizuno N, Kobayashi T, Yanagida A, Umino A, Ota Y, Hamanaka S, Masaki H, Rashid ST, Hirabayashi M, Nakauchi H. Interspecies organogenesis generates autologous functional islets. Nature 2017;542:191-196

18. Isotani A, Hatayama $\mathrm{H}$, Kaseda $\mathrm{K}$, Ikawa $\mathrm{M}$, Okabe $\mathrm{M}$. Formation of a thymus from rat ES cells in xenogeneic nude mouse $\leftrightarrow$ rat ES chimeras. Genes Cells 2011;16:397-405

19. Usui J, Kobayashi T, Yamaguchi T, Knisely AS, Nishinakamura R, Nakauchi H. Generation of kidney from pluripotent stem cells via blastocyst complementation. Am J Pathol 2012;180: 2417-2426

20. Yamanaka S, Tajiri S, Fujimoto T, Matsumoto K, Fukunaga S, Kim BS, Okano HJ, Yokoo T. Generation of interspecies limited chimeric nephrons using a conditional nephron progenitor cell replacement system. Nat Commun 2017;8: 1719

21. Goto T, Hara H, Sanbo M, Masaki H, Sato H, Yamaguchi T, Hochi S, Kobayashi T, Nakauchi H, Hirabayashi M. 
Generation of pluripotent stem cell-derived mouse kidneys in Sall1-targeted anephric rats. Nat Commun 2019;10:451

22. Watanabe $M$, Nakano $K$, Uchikura A, Matsunari H, Yashima S, Umeyama K, Takayanagi S, Sakuma T, Yamamoto T, Morita S, Horii T, Hatada I, Nishinakamura R, Nakauchi H, Nagashima H. Anephrogenic phenotype induced by SALL1 gene knockout in pigs. Sci Rep 2019;9:8016

23. Matsunari $H$, Watanabe $M$, Hasegawa $K$, Uchikura $A$, Nakano K, Umeyama K, Masaki H, Hamanaka S, Yamaguchi T, Nagaya M, Nishinakamura R, Nakauchi H, Nagashima H. Compensation of disabled organogeneses in genetically modified pig fetuses by blastocyst complementation. Stem Cell Reports 2020;14:21-33

24. Wu J, Platero-Luengo A, Sakurai M, Sugawara A, Gil MA, Yamauchi T, Suzuki K, Bogliotti YS, Cuello C, Morales Valencia M, Okumura D, Luo J, Vilariño M, Parrilla I, Soto DA, Martinez CA, Hishida T, Sánchez-Bautista S, Martinez-Martinez ML, Wang $\mathrm{H}$, Nohalez A, Aizawa E, Martinez-Redondo P, Ocampo A, Reddy P, Roca J, Maga EA, Esteban CR, Berggren WT, Nuñez Delicado E, Lajara J, Guillen I, Guillen P, Campistol JM, Martinez EA, Ross PJ, Izpisua Belmonte JC. Interspecies chimerism with mammalian pluripotent stem cells. Cell 2017;168:473-486. e15

25. Zhang H, Huang J, Li Z, Qin G, Zhang N, Hai T, Hong Q, Zheng Q, Zhang Y, Song R, Yao J, Cao C, Zhao J, Zhou Q. Rescuing ocular development in an anophthalmic pig by blastocyst complementation. EMBO Mol Med 2018;10: e8861

26. Steevens AR, Griesbach MW, You Y, Dutton JR, Low WC, Santi PA. Generation of inner ear sensory neurons using blastocyst complementation in a Neurog $1^{+} /{ }^{-}$-deficient mouse. Stem Cell Res Ther 2021;12:122

27. Mori M, Furuhashi K, Danielsson JA, Hirata Y, Kakiuchi M, Lin CS, Ohta M, Riccio P, Takahashi Y, Xu X, Emala CW, Lu C, Nakauchi H, Cardoso WV. Generation of functional lungs via conditional blastocyst complementation using pluripotent stem cells. Nat Med 2019;25:1691-1698

28. Kitahara A, Ran Q, Oda K, Yasue A, Abe M, Ye X, Sasaoka T, Tsuchida M, Sakimura K, Ajioka Y, Saijo Y, Zhou Q. Generation of lungs by blastocyst complementation in apneumic Fgf10-deficient mice. Cell Rep 2020;31:107626

29. Ran Q, Zhou Q, Oda K, Yasue A, Abe M, Ye X, Li Y, Sasaoka T, Sakimura K, Ajioka Y, Saijo Y. Generation of thyroid tissues from embryonic stem cells via blastocyst complementation in vivo. Front Endocrinol (Lausanne) 2020;11:609697

30. Wen B, Li E, Ustiyan V, Wang G, Guo M, Na CL, Kalin GT, Galvan V, Xu Y, Weaver TE, Kalin TV, Whitsett JA, Kalinichenko VV. In vivo generation of lung and thyroid tissues from embryonic stem cells using blastocyst complementation. Am J Respir Crit Care Med 2021;203:471-483

31. Ruiz-Estevez M, Crane AT, Rodriguez-Villamil P, Ongaratto FL, You Y, Steevens AR, Hill C, Goldsmith T, Webster DA, Sherry L, Lim S, Denman N, Low WC, Carlson DF, Dutton JR, Steer CJ, Gafni O. Liver develop- ment is restored by blastocyst complementation of HHEX knockout in mice and pigs. Stem Cell Res Ther 2021;12:292

32. Chubb R, Oh J, Riley AK, Kimura T, Wu SM, Wu JY. In vivo rescue of the hematopoietic niche by Pluripotent stem cell complementation of defective osteoblast compartments. Stem Cells 2017;35:2150-2159

33. Maeng G, Das S, Greising SM, Gong W, Singh BN, Kren S, Mickelson D, Skie E, Gafni O, Sorensen JR, Weaver CV, Garry DJ, Garry MG. Humanized skeletal muscle in MYF5/MYOD/MYF6-null pig embryos. Nat Biomed Eng 2021 [Epub ahead of print]

34. Kobayashi T, Goto T, Oikawa M, Sanbo M, Yoshida F, Terada R, Niizeki N, Kajitani N, Kazuki K, Kazuki Y, Hochi S, Nakauchi H, Surani MA, Hirabayashi $M$. Blastocyst complementation using Prdm14-deficient rats enables efficient germline transmission and generation of functional mouse spermatids in rats. Nat Commun 2021;12: 1328

35. Hamanaka S, Umino A, Sato H, Hayama T, Yanagida A, Mizuno N, Kobayashi T, Kasai M, Suchy FP, Yamazaki S, Masaki H, Yamaguchi T, Nakauchi H. Generation of vascular endothelial cells and hematopoietic cells by blastocyst complementation. Stem Cell Reports 2018;11:988-997

36. Wang G, Wen B, Ren X, Li E, Zhang Y, Guo M, Xu Y, Whitsett JA, Kalin TV, Kalinichenko VV. Generation of pulmonary endothelial progenitor cells for cell-based therapy using interspecies mouse-rat chimeras. Am J Respir Crit Care Med 2021;204:326-338

37. Das S, Koyano-Nakagawa N, Gafni O, Maeng G, Singh BN, Rasmussen T, Pan X, Choi KD, Mickelson D, Gong W, Pota P, Weaver CV, Kren S, Hanna JH, Yannopoulos D, Garry MG, Garry DJ. Generation of human endothelium in pig embryos deficient in ETV2. Nat Biotechnol 2020;38: 297-302

38. Vilarino M, Rashid ST, Suchy FP, McNabb BR, van der Meulen T, Fine EJ, Ahsan SD, Mursaliyev N, Sebastiano V, Diab SS, Huising MO, Nakauchi H, Ross PJ. CRISPR/ Cas9 microinjection in oocytes disables pancreas development in sheep. Sci Rep 2017;7:17472

39. Wang J, Liu M, Zhao L, Li Y, Zhang M, Jin Y, Xiong Q, Liu X, Zhang L, Jiang H, Chen Q, Wang C, You Z, Yang H, Cao C, Dai Y, Li R. Disabling of nephrogenesis in porcine embryos via CRISPR/Cas9-mediated SIX1 and SIX4 gene targeting. Xenotransplantation 2019;26:e12484

40. Kobayashi T, Kato-Itoh M, Nakauchi H. Targeted organ generation using Mixll-inducible mouse pluripotent stem cells in blastocyst complementation. Stem Cells Dev 2015; 24:182-189

41. Hashimoto H, Eto T, Yamamoto M, Yagoto M, Goto M, Kagawa T, Kojima K, Kawai K, Akimoto T, Takahashi RI. Development of blastocyst complementation technology without contributions to gametes and the brain. Exp Anim 2019;68:361-370

42. Masaki H, Kato-Itoh M, Takahashi Y, Umino A, Sato H, Ito K, Yanagida A, Nishimura T, Yamaguchi T, Hirabayashi M, Era T, Loh KM, Wu SM, Weissman IL, Nakauchi H. 
Inhibition of apoptosis overcomes stage-related compatibility barriers to chimera formation in mouse embryos. Cell Stem Cell 2016;19:587-592

43. Lyons I, Parsons LM, Hartley L, Li R, Andrews JE, Robb L, Harvey RP. Myogenic and morphogenetic defects in the heart tubes of murine embryos lacking the homeo box gene Nkx2-5. Genes Dev 1995;9:1654-1666

44. Yamaguchi T, Sato H, Kobayashi T, Kato-Itoh M, Goto T, Hara H, Mizuno N, Yanagida A, Umino A, Hamanaka S, Suchy F, Masaki H, Ota Y, Hirabayashi M, Nakauchi H. An interspecies barrier to tetraploid complementation and chimera formation. Sci Rep 2018;8:15289

45. Masaki H, Kato-Itoh M, Umino A, Sato H, Hamanaka S, Kobayashi T, Yamaguchi T, Nishimura K, Ohtaka $M$, Nakanishi $M$, Nakauchi $H$. Interspecific in vitro assay for the chimera-forming ability of human pluripotent stem cells. Development 2015;142:3222-3230

46. Tesar PJ, Chenoweth JG, Brook FA, Davies TJ, Evans EP, Mack DL, Gardner RL, McKay RD. New cell lines from mouse epiblast share defining features with human embryonic stem cells. Nature 2007;448:196-199

47. Brons IG, Smithers LE, Trotter MW, Rugg-Gunn P, Sun B, Chuva de Sousa Lopes SM, Howlett SK, Clarkson A, Ahrlund-Richter L, Pedersen RA, Vallier L. Derivation of pluripotent epiblast stem cells from mammalian embryos. Nature 2007;448:191-195

48. Takahashi S, Kobayashi S, Hiratani I. Epigenetic differences between naive and primed pluripotent stem cells. Cell Mol Life Sci 2018;75:1191-1203

49. Weinberger L, Ayyash M, Novershtern N, Hanna JH. Dynamic stem cell states: naive to primed pluripotency in rodents and humans. Nat Rev Mol Cell Biol 2016;17:155169

50. Mascetti VL, Pedersen RA. Human-mouse chimerism validates human stem cell pluripotency. Cell Stem Cell 2016; 18:67-72

51. Hanna J, Cheng AW, Saha K, Kim J, Lengner CJ, Soldner F, Cassady JP, Muffat J, Carey BW, Jaenisch R. Human embryonic stem cells with biological and epigenetic characteristics similar to those of mouse ESCs. Proc Natl Acad Sci U S A 2010;107:9222-9227

52. Chan YS, Göke J, Ng JH, Lu X, Gonzales KA, Tan CP, Tng WQ, Hong ZZ, Lim YS, Ng HH. Induction of a human pluripotent state with distinct regulatory circuitry that resembles preimplantation epiblast. Cell Stem Cell 2013;13: 663-675

53. Gafni O, Weinberger L, Mansour AA, Manor YS, Chomsky E, Ben-Yosef D, Kalma Y, Viukov S, Maza I, Zviran A, Rais Y, Shipony Z, Mukamel Z, Krupalnik V, Zerbib M, Geula S, Caspi I, Schneir D, Shwartz T, Gilad S, AmannZalcenstein D, Benjamin S, Amit I, Tanay A, Massarwa R, Novershtern N, Hanna JH. Derivation of novel human ground state naive pluripotent stem cells. Nature 2013;504: 282-286

54. Takashima Y, Guo G, Loos R, Nichols J, Ficz G, Krueger F, Oxley D, Santos F, Clarke J, Mansfield W, Reik W,
Bertone P, Smith A. Resetting transcription factor control circuitry toward ground-state pluripotency in human. Cell 2014;158:1254-1269

55. Theunissen TW, Powell BE, Wang H, Mitalipova M, Faddah DA, Reddy J, Fan ZP, Maetzel D, Ganz K, Shi L, Lungjangwa T, Imsoonthornruksa S, Stelzer Y, Rangarajan S, D'Alessio A, Zhang J, Gao Q, Dawlaty MM, Young RA, Gray NS, Jaenisch R. Systematic identification of culture conditions for induction and maintenance of naive human pluripotency. Cell Stem Cell 2014;15:471-487

56. Wu J, Okamura D, Li M, Suzuki K, Luo C, Ma L, He Y, Li Z, Benner C, Tamura I, Krause MN, Nery JR, Du T, Zhang Z, Hishida T, Takahashi Y, Aizawa E, Kim NY, Lajara J, Guillen P, Campistol JM, Esteban CR, Ross PJ, Saghatelian A, Ren B, Ecker JR, Izpisua Belmonte JC. An alternative pluripotent state confers interspecies chimaeric competency. Nature 2015;521:316-321

57. Yang Y, Liu B, Xu J, Wang J, Wu J, Shi C, Xu Y, Dong J, Wang C, Lai W, Zhu J, Xiong L, Zhu D, Li X, Yang W, Yamauchi T, Sugawara A, Li Z, Sun F, Li X, Li C, He A, Du Y, Wang T, Zhao C, Li H, Chi X, Zhang H, Liu Y, Li C, Duo S, Yin M, Shen H, Belmonte JCI, Deng H. Derivation of pluripotent stem cells with in vivo embryonic and extraembryonic potency. Cell 2017;169:243-257. e25

58. Fu R, Yu D, Ren J, Li C, Wang J, Feng G, Wang X, Wan H, Li T, Wang L, Zhang Y, Hai T, Li W, Zhou Q. Domesticated cynomolgus monkey embryonic stem cells allow the generation of neonatal interspecies chimeric pigs. Protein Cell 2020;11:97-107

59. Yu L, Wei Y, Sun HX, Mahdi AK, Pinzon Arteaga CA, Sakurai M, Schmitz DA, Zheng C, Ballard ED, Li J, Tanaka N, Kohara A, Okamura D, Mutto AA, Gu Y, Ross PJ, Wu J. Derivation of intermediate pluripotent stem cells amenable to primordial germ cell specification. Cell Stem Cell 2021;28:550-567.e12

60. Aksoy I, Rognard C, Moulin A, Marcy G, Masfaraud E, Wianny F, Cortay V, Bellemin-Ménard A, Doerflinger N, Dirheimer $M$, Mayère $C$, Bourillot $P Y$, Lynch $C$, Raineteau O, Joly T, Dehay C, Serrano M, Afanassieff M, Savatier P. Apoptosis, G1 phase stall, and premature differentiation account for low chimeric competence of human and rhesus monkey naive pluripotent stem cells. Stem Cell Reports 2021;16:56-74

61. Pampfer S, Donnay I. Apoptosis at the time of embryo implantation in mouse and rat. Cell Death Differ 1999;6:533545

62. Fabian D, Koppel J, Maddox-Hyttel P. Apoptotic processes during mammalian preimplantation development. Theriogenology 2005;64:221-231

63. Oestrup O, Hall V, Petkov SG, Wolf XA, Hyldig S, Hyttel P. From zygote to implantation: morphological and molecular dynamics during embryo development in the pig. Reprod Domest Anim 2009;44 Suppl 3:39-49

64. Wang X, Li T, Cui T, Yu D, Liu C, Jiang L, Feng G, Wang L, Fu R, Zhang X, Hao J, Wang Y, Wang L, Zhou Q, Li 
W, Hu B. Human embryonic stem cells contribute to embryonic and extraembryonic lineages in mouse embryos upon inhibition of apoptosis. Cell Res 2018;28:126-129

65. Huang K, Zhu Y, Ma Y, Zhao B, Fan N, Li Y, Song H, Chu S, Ouyang Z, Zhang Q, Xing Q, Lai C, Li N, Zhang T, Gu J, Kang B, Shan Y, Lai K, Huang W, Mai Y, Wang Q, Li J, Lin A, Zhang Y, Zhong X, Liao B, Lai L, Chen J, Pei D, Pan G. BMI1 enables interspecies chimerism with human pluripotent stem cells. Nat Commun 2018;9:4649

66. Zheng C, Ballard EB, Wu J. The road to generating transplantable organs: from blastocyst complementation to interspecies chimeras. Development 2021;148:dev195792

67. Wu J, Greely HT, Jaenisch R, Nakauchi H, Rossant J, Belmonte JC. Stem cells and interspecies chimaeras. Nature 2016;540:51-59

68. De Los Angeles A, Elsworth JD, Redmond DE Jr. ERK-independent African Green monkey pluripotent stem cells in a putative chimera-competent state. Biochem Biophys Res Commun 2019;510:78-84

69. Nowak-Imialek M, Wunderlich S, Herrmann D, BreitschuhLeibling S, Gohring G, Petersen B, Klein S, Baulain U, Lucas-Hahn A, Martin U, Niemann H. In vitro and in vivo interspecies chimera assay using early pig embryos. Cell Reprogram 2020;22:118-133

70. Akhlaghpour A, Taei A, Ghadami SA, Bahadori Z, Yakhkeshi S, Molamohammadi S, Kiani T, Samadian A, Ghezelayagh Z, Haghparast N, Khalooghi $\mathrm{K}$, Braun $\mathrm{T}$, Baharvand $\mathrm{H}$, Hassani SN. Chicken interspecies chimerism unveils human pluripotency. Stem Cell Reports 2021;16:39-55

71. Tan T, Wu J, Si C, Dai S, Zhang Y, Sun N, Zhang E, Shao $\mathrm{H}$, Si W, Yang P, Wang H, Chen Z, Zhu R, Kang Y, Hernandez-Benitez R, Martinez Martinez L, Nuñez Delicado E, Berggren WT, Schwarz M, Ai Z, Li T, Rodriguez Esteban C, Ji W, Niu Y, Izpisua Belmonte JC. Chimeric contribution of human extended pluripotent stem cells to monkey embryos ex vivo. Cell 2021;184:2020-2032.e14

72. Nishimura T, Suchy FP, Bhadury J, Igarashi KJ, Charlesworth CT, Nakauchi H. Generation of functional organs using a cell-competitive niche in intra- and inter-species rodent chimeras. Cell Stem Cell 2021;28:141-149.e3

73. Steering Committee of the Istanbul Summit. Organ trafficking and transplant tourism and commercialism: the Declaration of Istanbul. Lancet 2008;372:5-6 